\title{
Early Activation Antigen CD69
}

National Cancer Institute

\section{Source}

National Cancer Institute. Early Activation Antigen CD69. NCI Thesaurus. Code C104076.

Early activation antigen CD69 (199 aa, $23 \mathrm{kDa}$ ) is encoded by the human CD69 gene.

This protein plays a role in signal transduction in natural killer cells and platelets. 